\title{
Model Pembelajaran Tari Kreatif untuk Meningkatkan Percaya Diri Anak Usia Taman Kanak-Kanak
}

\author{
1I GUSTI KOMANG ARYAPRASTA AGUS, 2ARIE RAKHMAT RIYADI \\ 1,2 Program Studi Pendidikan Anak Usia Dini, \\ Universitas Pendidikan Indonesia \\ Email: 1 igustikomangarya@upi.edu, 2 arie.riyadi@upi.edu
}

Article Received: 19-07-2018

Published Article: 07-11-2018

DOI: https://doi.org/10.29313/ga.v2i1.3864

\begin{abstract}
This research is motivated by the need for the stimulation of early childhood development. Various aspects of child development, including social-emotional learning methods that are appropriate to the characteristics of child development. Confidence in children is an integral part of primary education, especially early childhood education. Various learning approaches should be able to boost it to increase optimally developed. Dance learning that has been identical to train the things that are physiological was identified to have advantages regarding the formation of the child's personality. The purpose of this study is to develop creative dance learning tools that are expected to increase the confidence of children, especially children of kindergarten age (TK). Research method using action research/action research as much as three cycles. Research subjects are kindergarten children consisting of two kindergartens, the kindergarten Labschool UPI and Kartika Candra Gegerkalong Kindergarten. The results of this study in addition to creative dance learning devices are tested, also proves creative dance learning can increase the confidence of kindergarten children.
\end{abstract}

Keywords: Dance, Creative, Creativity, Confidence, Learning, and Kindergarten Children.

\begin{abstract}
Abstrak
Penelitian ini dilatarbelakangi oleh kebutuhan stimulasi perkembangan anak usia dini. Beragam aspek perkembangan anak termasuk sosial-emosional memerlukan metode pembelajaran yang sesuai dengan karakteristik perkembangan anak. Rasa percaya diri pada anak merupakan bagian penting dalam pendidikan dasar, khususnya pendidikan usia dini. Beragam pendekatan pembelajaran harus mampu mengdongkrak hal tersebut agar meningkat ditumbuh-kembangkan secara optimal. Pembelajaran tari yang selama ini identik melatih hal-hal yang bersifat fisiologis ternyata diidentifikasi memiliki kelebihan dalam hal pembentukan kepribadian anak. Tujuan penelitian ini adalah untuk mengembangkan perangkat pembelajaran tari kreatif yang diharapkan dapat meningkatkan rasa percaya diri anak, khususnya anak usia taman kanak-kanak (TK). Metode penelitian menggunakan penelitian tindakan/ action research sebanyak 3 siklus. Subjek penelitian adalah anak TK Labschool UPI. Hasil penelitian ini selain perangkat pembelajaran tari kreatif yang teruji, juga membuktikan pembelajaran tari kreatif dapat meningkatkan percaya diri anak usia TK.
\end{abstract}

Kata Kunci: Tari, Kreatif, Kreativitas, Percaya Diri, Pembelajaran, dan Anak TK.

\section{Pendahuluan}

Pendidikan merupakan salah satu hal yang penting untuk anak. Sejak lahir anak memperoleh pendidikan pertama dari keluarga. Namun hal tersebut tidaklah cukup karena anak juga membutuhkan pendidikan formal. Pendidikan anak usia dini merupakan batu loncatan yang paling dasar dan berpengaruh besar untuk keberhasilan pendidikan selanjutnya. Sebagaimana disebutkan dalam UndangUndang Sistem Pendidikan Nasional (2003) pada pasal 1 ayat (14) dinyatakan bahwa: 
"Pendidikan anak usia dini adalah suatu upaya pembinaan yang ditujukan kepada anak sejak lahir sampai dengan usia enam tahun yang dilakukan melalui pemberian rangsangan pendidikan untuk membantu pertumbuhan dan perkembangan jasmani dan rohani agar anak memiliki kesiapan dalam memasuki pendidikan lebih lanjut."

Sujiono (2010: 6) menyatakan bahwa anak usia dini (dari lahir sampai usia delapan tahun) anak mengalami masa keemasan (the golden years), dimana anak tersebut sangat peka terhadap pengaruh dan perubahan yang berasal dari lingkungan sekitarnya.

Pada masa keemasan ini merupa- kan waktu yang sangat baik untuk mengoptimalkan aspek perkembangannya. Aspek- perkembangan anak antara lain meliputi perkembangan fisik dan motorik, perkembangan kognitif, perkembangan bahasa dan berbicara serta perkembangan sosio emosional. Semua aspek tersebut dapat dikembangkan melalui pembelajaran yang ada di pendidikan anak usia dini jalur formal, misalnya Taman Kanak-Kanak (TK), Raudathul Athfal (RA) atau bentuk lain yang sederajat.

TK merupakan salah satu wadah yang dapat membantu tumbuh kembang anak sesuai dengan tingkat perkembangannya. Hal ini diperkuat oleh Suyadi (2014:26) bahwa "pada jenjang Taman Kanak-Kanak, anak mulai diberi pendidikan secara berencana dan sistematis agar pendidikan yang diberikan lebih bermakna bagi anak, dan TK harus tetap menjadi tempat yang menyenangkan bagi anak". Anak-anak mulai belajar untuk berkomunikasi, bersosialisasi bahkan anak dapat mengembangkan percaya diri sejak dini. Salah satu cara untuk mengembangkan rasa percaya diri anak adalah melalui seni.

Salah satu kegiatan yang dapat dikembangkan di Taman Kanak-Kanak adalah kegiatan seni seperti seni tari. Seni tari dapat disesuaikan dengan perkembangan anak TK, karena aktivitas bergerak pada anak TK sangat dominan sehingga pembelajaran melalui tari sangat cocok untuk mengoptimalkan perkembangan gerak/ motorik anak.

Dalam konteks pendidikan anak usia dini, Suyadi (2014:167) menyatakan bahwa kegiatan bermain, bernyanyi, menggambar, menari (gerak dan lagu) merupakan aktivitas seni yang sangat mendasar. Adapun tariantarian dan gerakan badan selama bermain mampu mengembangkan motorik kasar. Oleh karena itu, perkembangan motorik kasar dapat dilatih dengan pembelajaran seni tari untuk anak TK.

Dalam kurikulum TK 2004 termuat bidang pengembangan kemampuan dasar yang meliputi pengembangan kemampuan seni. Ketika anak mencapai usia 3 sampai

6 tahun telah tampak otot-otot tubuh yang berkembang sehingga memungkinkan mereka melakukan berbagai jenis keterampilan. Jenis keterampilan yang sesuai dengan pembelajaran seni tari yakni perkembangan motorik kasar. Anak dapat melakukan gerakan melompat, mendorong dan berjalan, kemudian kemampuan motorik kasar tersebut dapat dilakukan dengan menggunakan musik sehingga kegiatan ini akan lebih menarik bagi anak.

Berdasarkan hasil observasi yang telah dilakukan di TK Kartika Candra, dan bahkan di TK Labschool UPI bahwa umumnya metode yang masih dipakai di sekolah TK yakni metode imitasi, anak hanya meniru gerakan tari yang diajarkan oleh guru tanpa ada proses timbal balik sehingga metode ini justru terfokus pada guru. Oleh karena itu, Metode di TK seharusnya berpusat pada anak. Dampak dari metode terpusat pada guru berpengaruh pula pada aspek-aspek kreativitas anak. Anak-anak kurang berani dalam mengungkapkan ide atau gagasan kreatif dan anak juga kurang percaya diri ketika menari. Oleh karena itu, pembelajaran berpusat pada anak adalah program tahap demi tahap yang didasari pada adanya suatu keyakinan bahwa anak-anak dapat tumbuh dengan baik jika mereka dilibatkan secara alamiah dalam proses belajar. Jika hal ini dibiarkan terus menerus maka anak akan sulit bersikap ataupun berfikir kreatif.

Dalam hal menciptakan produk kreatif melalui penciptaan gerak tari masih terlalu sulit bagi anak karena belum sesuai dengan tingkat perkembangan anak, namun dalam pembelajaran seni tari dapat dilihat dan diamati dari segi proses perkembangan kreativitas anak melalui ciri-ciri kepribadian kreatif yang muncul. Agar pembelajaran sesuai dengan tingkat perkembangan anak dan anak dapat mengembangkan kreativitas maka strategi belajar sambil bermain sangat cocok untuk anak usia Taman Kanak-Kanak. 
Untuk mengatasi berbagai masalah maka guru dan peneliti merasa perlu adanya perbaikan dalam proses belajar terutama seni tari. Dalam hal ini dipilih strategi pembelajaran tari kreatif. Penggunaan dari strategi pembelajaran tari kreatif memberikan kesempatan pada individu untuk berpikir dan bertindak imajinatif, serta penuh daya hayal yang erat hubungannya dengan perkembangan rasa percaya diri (Melati,2012: 86). Melalui stimulan pembelajaran tari kreatif anak dapat mempelajari banyak hal, tanpa ia sadari dan tanpa merasa terbebani (Rahmawati dan Kurniati, 2005:46). Anak dapat mengungkapkan ide-ide kreatif dan anak tidak kehilangan masa bermainnya.

Berdasarkan uraian pada bagian latar belakang, penelitian ini dibatasi pada pengembangan dan implementasi pembelajaran tari kreatif dengan harapan hal tersebut akan mendongkrak percaya diri anak TK. Untuk pengembangan pembelajaran tari kreatif ini sendiri dikonstruksi merujuk pada konstruk dari Joyce dan Weil (1982), yaitu:

(1) syntax, langkah-langkah operasional pembelajaran; (2) social system, adalah suasana dan norma yang berlaku dalam pembelajaran; (3) principles of reaction, menggambarkan bagaimana seharusnya guru memandang, memperlakukan, dan merespon siswa; (4) support system, segala sarana, bahan, alat, atau lingkungan belajar yang mendukung pembelajaran; dan (5) instructional dan nurturant effects-hasil belajar yang diperoleh langsung berdasarkan tujuan yang ditetapkan (instructional effects) dan hasil belajar di luar yang ditetapkan (nurturant effects). Kemudian untuk konsep kreativitas akan menggunakan konstruk yang dikembangkan oleh Jamaris (Sujiono, 2010), mencakup lima ciri perilaku kreatif tersebut yakni kelancaran (fluency), kelenturan (flexibility), keaslian (originality), elaborasi (elaboration) dan kepekaan (sensitivity). Selanjutnya yang terakhir tentang konsep percaya diri (self confidence) merujuk pada konsep Bush (2003) terkait tiga hal, yakni penampilan fisik, kapabilitas intelektual dan ekspresi emosi yang tepat.

Berdasarkan latar belakang penelitian dan batasannya, maka rumusan masalah utama penelitian adalah menjawab p e $r \mathrm{t} a$ n y a a n, " b a ga i m a n a d a m p a k implementasi model pembelajaran tari kreatif terhadap peningkatan kreativitas dan percaya diri anak usia TK?".
Menurut Kusuma (2007: 53), pendidikan merupakan sebuah proses yang membantu menumbuhkan, mengembangkan, mendewasakan, membuat yang tidak tertata atau liar menjadi semakin tertata, semacam proses penciptaan sebuah kultur dan tata keteraturan dalam diri maupun dalam diri orang lain. Pendidikan dapat di peroleh anak melalui pendidikan formal maupun nonformal, namun pendidikan yang tidak kalah penting yakni pendidikan yang ditanamkan kepada anak sejak kecil. Baik dalam lingkungan keluarga maupun lingkungan sosial.

Seni merupakan salah satu aspek yang penting dalam dunia pendidikan. Selanjutnya, Suyadi (2014: 165) mengatakan bahwa PAUD mempunyai kontribusi besar bagi pelestarian budaya bangsa melalui pembelajaran seni dengan beragam ekspresinya. Pada anakanak atau Pendidikan Anak Usia Dini (PAUD), kegiatan bermain, bernyanyi, menggambar, menari (gerak dan lagu) merupakan aktivitas seni yang sangat mendasar. Adapun tariantarian dan gerakan-gerakan selama bermain mampu mengembangkan keterampilan motorik kasar, dan keseluruhan aktivitasaktivitas ini meningkatkan emosional anak.

Pembelajaran tari kreatif pada dasarnya berusaha untuk memperkuat dan memperlancar stimulus dan respons anak didik dalam pembelajaran, sehingga proses pembelajaran menjadi hal yang menyenangkan, tidak menjadi hal yang membosankan bagi mereka. Efek menyenangkan yang ditimbulkan stimulus akan mampu memberi kesan yang mendalam pada diri anak didik, sehingga mereka cenderung akan mengulang aktivitas tersebut (Hartono, 2008: 1).

Oleh karena itu, pendidikan seni tari kreatif merupakan suatu pembelajaran yang dapat membatu anak usia dini mengembangkan berbagai kemampuan di masa golden age. Selain itu, melalui seni tari maka pendidik dapat menjadi fasilitator anak untuk mengembangkan kreativitas. Dalam kreativitas anak usia dini, maka yang lebih disorot dan dikembangkan adalah proses kreativitasnya dan identifikasi ciri-ciri anak kreatif serta keterampilan pribadinya yang terwujud melalui rasa percaya diri (selfconfidence) yang optimal. 


\section{Konsep Tari dan Pembelajaran Tari Kreatif untuk Anak Usia TK}

Tari adalah gerak yang telah mengalami proses stimulasi sesuai dengan irama sebagai ungkapan jiwa manusia yang di dalamnya terdapat unsur keindahan. Tari untuk anak TK adalah gerak berirama yang ritmis dan indah sesuai dengan karakteristik perkembangan anak usia TK, kegiatannya bersifat kreatif dan kontruktif serta menumbuhkan kreativitas anak (Desfina, 2005: 4) Tari memberikan ruang kepada anak untuk bermain dan berimajinasi, misalnya dengan berekspresi diri menjadi peran tertentu dalam sebuah tarian dan mengembangkan sebuah gagasan melalui kreativitas gerak tari. Selain itu tari melatih kognisi dan konsentrasi anak untuk fokus menguasai urutan gerak tari dari awal sampai akhir. Dengan demikian melalui tari anakanak belajar untuk membiasakan diri berlatih menguasai gerak ataupun urutan rangkaian gerak sebagai materi dasar sebuah tarian (Dewi, 2008: 5).

Belajar menari di Taman Kanak-kanak semata -mata bukanlah untuk menguasai sebuah produk tarian jadi (tari bentuk) untuk tujuan pertunjukan. Namun mempunyai tujuan yang lebih luas dalam proses membentuk pribadi anak melalui pengalaman belajar menari dan berpentas. Belajar melalui tari berarti belajar untuk berekspresi diri melalui gerak di dalam ruang. Melalui ekspresi diri dalam menari anak belajar beraktualisasi diri khususnya pada pertunjukan tari sebagai hasil belajar anak (Dewi, 2008: 5).

Menari pada dasarnya dapat dilakukan secara individu, berpasangan maupun kelompok. Sehingga selain sebagai ekspresi individu, tari berfungsi sebagai latihan bagi anak untuk bersosialisasi membangun kebersamaan sambil bermain bagi anak baik dengan pasangannya maupun kelompoknya dalam menari dan belajar untuk mengatasi masalah (problem solving) yang timbul dari dirinya maupun kelompoknya dengan bimbingan guru. Selain itu tari sangat berhubungan erat dengan musik sebagai pengiringnya Melalui gerakannya anak belajar memahami ritme maupun suasana yang ada dalam musik pengiring tarinya (Dewi, 2008: 5).

\section{Tujuan Pembelajaran Tari Untuk Anak Taman Kanak-kanak}

Menurut Desfina (2005: 14) Tari merupakan salah satu kegiatan seni yang dapat menumbuhkan kreativitas anak Taman kanak-kanak. Dengan menari anak akan mendapatkan pengalaman baru dalam berekspresi melalui geraknya. Kegiatan menari merupakan salah satu upaya untuk meningkatkan kreativitas, keterampilan fisik serta emosi, kepribadian, kedisiplinan agar anak dapat berkembang secara optimal. Desfina (2005:14) Tujuan tari untuk anak taman kanak-kanak ada beberapa macam, tujuan tersebut antara lain sebagai berikut. Menanamkan pengaruh yang bermanfaat atau positif dari kegiatan menari kreatif terhadap terhadap pembentukan jiwa anak dalam rangka mengembangkan daya cipta anak terhadap tarian dan juga dapat dijadikan sebagai suatu pertunjukkan seni untuk anak.

Mengembangkan kepekaan anak untuk berekspresi dan mengembangkan daya nalar anak berimajinasi.

Memancing kreativitas anak karena dengan menari anak tertantang untuk kreatif dalam bergerak.

Merangsang emosi anak karena dalam menari anak akan tergugah emosinya untuk melakukan gerak yang sesuai dengan keinginan anak dan rasa senang anak.

Membantu anak supaya lebih percaya diri dan membebaskan anak dari ketakutan karena anak bergerak secara bebas dan dapat berkomunikasi bebas dengan temantemannya.

Anak dapat mengimplementasikan perasaan dirinya yang dekat dengan alam lingkungan sekitar anak.

\section{Konsep Percaya Diri (Self-Confi- dence)}

Self-confidence atau percaya diri adalah sejauh mana adanya keyakinan terhadap penilaian atas kemampuan untuk berhasil. Ignoffo (1999) secara sederhana mendefinisikan self confidence berarti memiliki keyakinan terhadap diri sendiri. Menurut Neill, self confidence adalah kombinasi dari self esteem dan self-efficacy.

Lauster (1978), menyatakan bahwa self confidence merupakan suatu sikap atau perasaan yakin atas kemampuan diri sendiri sehingga orang yang bersangkutan tidak terlalu cemas dalam tindakan-tindakannya, dapat merasa bebas untuk melakukan hal-hal yang disukainya dan bertanggung jawab atas perbuatannya, hangat dan sopan dalam berinteraksi dengan orang lain, dapat 
menerima dan menghargai orang lain, memiliki dorongan untuk berprestasi serta dapat mengenal kelebihan dan kekurangannya. Self confidence adalah sikap positif seorang individu yang merasa memiliki kompetensi atau kemampuan untuk mengembangkan penilaian positif baik terhadap dirinya maupun lingkungan. Self confidence adalah percaya akan kemampuan sendiri yang memadai dan menyadari kemampuan yang dimiliki, serta dapat memanfaatkan secara tepat.

Coopersmith (1996) menjelaskan bahwa ketika individu lebih aktif, mempunyai perilaku yang bertujuan, bersemangat dalam menjalankan kehidupan sehari-hari baik yang bersifat individual maupun yang bersifat kelompok cenderung memiliki self confidence yang tinggi. Sedangkan menurut Hakim (2002) menjelaskan self confidence yaitu sebagai suatu keyakinan seseorang terhadap segala aspek kelebihan yang dimilikinya dan keyakinan tersebut membuatnya merasa mampu untuk dapat mencapai berbagai tujuan dalam hidupnya. Menurut Al-Uqshari (2005) self confidence adalah keyakinan seorang individu akan kemampuan yang dimiliki sehingga merasa puas dengan keadaan dirinya.

Bandura (2005) mendefinisikan self confidence sebagai suatu keyakinan seseorang yang mampu berperilaku sesuai dengan yang diharapkan dan diinginkan. Sedangkan Breneche dan Amich (Kumara, 1988) self confidence merupakan suatu perasaan cukup aman dan tahu apa yang dibutuhkan dalam kehidupannya sehingga tidak perlu membandingkan dirinya dengan orang lain dalam menentukan standar, karena ia selalu dapat menentukan sendiri. Menurut Hakim (2002) rasa percaya diri tidak muncul begitu saja pada diri seseorang, tetapi ada proses tertentu didalam pribadinya sehingga terjadilah pembentukan rasa percaya diri itu. Terbentuknya rasa percaya diri yang kuat terjadi melalui proses-proses berikut.

Terbentuknya kepribadian yang baik sesuai dengan proses perkembangan yang melahirkan kelebihan kelebihan tertentu.

Pemahaman seseorang terhadap kelebihan- kelebihan yang dimilikinya dan melahirkan keyakinan kuat untuk bisa berbuat segala sesuatu dengan memanfaatkan kelebihan-kelebihannya tersebut.

Pemahaman dan reaksi positif seseorang terhadap kelemahan-kelemahan yang dimilikinya agar tidak menimbulkan rasa rendah diri atau rasa sulit menyesuaikan diri.
Pengalaman didalam menjalani berbagai aspek kehidupan dengan menggunakan segala kelebihan yang ada pada dirinya.

\section{Pembelajaran Tari Kreatif untuk Me- ningkatkan Percaya Diri Anak Usia Taman Kanak-Kanak}

Rasa percaya diri anak dapat ditingkatkan melalui kegiatan pembelajaran dan faktor lingkungan. Kreativitas dapat timbul jika anak mendapatkan motivasi pada diri anak itu sendiri. Kreativitas yang dapat diterapkan melalui kreativitas tari. Soedarsono (Suryadewi, dkk, 1998 :170) mengemukakan tentang tari adalah ekspresi jiwa manusia melalui gerak-gerak ritmis yang indah. Kegiatan menari banyak dilakukan oleh Anak Taman kanak- kanak, Sekolah Dasar, Sekolah menengah Umum, Sekolah Menengah Atas, Perguruan Tinggi dan bahkan Orang Tua pun masih banyak yang mengikuti kegiatan menari. Tari kreatif diberikan agar membantu anak memiliki kemampuan serta minat anak dalam pembelajaran tari khususnya untuk mengembangkan, menumbuhkan dan menciptakan suatu yang baru daya kreativitasnya melalui gerakan yang diciptakannya secara alami sehingga tercipta suatu karya seni dalam bentuk suatu tarian. Tari kreatif dapat dilakukan dalam pembelajaran tari secara individual maupun kelompok. Tujuan dari tari kreatif khususnya dalam pembelajaran tari yaitu sebagai penambahan metode baru dalam pembelajaran tari yang diberikan kepada siswa untuk menambah dan mengembangkan kreativitasnya melalui penciptaan-penciptaan gerak tari yang dilakukan oleh siswa itu sendiri dan dirangsang oleh salah satu rangsangan dalam tari.

Pembelajaran tari kreatif anak dapat belajar untuk mengoptimalkan penggunaan semua potensi yang dimiliki oleh anak didik, sehingga semua anak didik dapat mencapai hasil belajar yang memuaskan sesuai dengan karakteristik pribadi yang mereka miliki. Proses pembelajaran tari pada dasarnya merupakan pemberian stimulus-stimulus kepada anak didik, agar terjadinya respons yang positif pada diri anak didik. Kesediaan dan kesiapan mereka dalam mengikuti proses demi proses dalam pembelajaran akan mampu menimbulkan respons yang baik terhadap stimulus yang mereka terima dalam proses pembelajaran (Hartono, 2008: 1). Pembelajaran tari kreatif pada dasarnya berusaha untuk 
memperkuat dan memperlancar stimulus dan respons anak didik dalam pembelajaran, sehingga proses pembelajaran menjadi hal yang menyenangkan, tidak menjadi hal yang membosankan bagi mereka. Efek menyenangkan yang ditimbulkan stimulus akan mampu memberi kesan yang mendalam pada diri anak didik, sehingga mereka cenderung akan mengulang aktivitas tersebut (Hartono, 2008: 1).

Dapat disimpulkan bahwa pembelajaran tari kreatif sangat penting dalam pembelajaran tari karena merupakan suatu model pembelajaran yang dapat membangkitkan semangat anak, khususnya dalam menemukan ide, aktif dalam menciptakan kreasi tari serta membantu guru untuk mengoptimalkan tugasnya dalam fungsi serta peranannya sebagai guru yang dapat memotivasi anak untuk berfikir secara aktif dan kreatif serta memberikan stimulusstimulus yang menyenangkan dan disesuaikan dengan kebutuhan dan karakteristik anak sehingga pembelajaran tari kreatif dapat berjalan dengan optimal.

Beberapa hal yang telah dicapai dan dilakukan untuk mendukung penelitian ini adalah melakukan kajian teoretik terkait konseptualisasi kreativitas dan percaya diri (self-confidence) pada anak. Utamanya sejumlah hasil kajian tentang pembelajaran tari kreatif beberapa diantaranya telah dapat disesuaikan dengan konsep dan kerangka model pembelajaran dari Joyce \& Weill (1993).

Observasi yang dilakukan di target subjek penelitian yaitu TK Labschool UPI dan TK Pandiga Cimahi menunjukkan umumnya metode yang masih dipakai di sekolah TK yakni metode imitasi, anak hanya meniru gerakan tari yang diajarkan oleh guru tanpa ada proses timbal balik sehingga metode ini justru terfokus pada guru, tidak mengembangkan kreativitas anak dan tidak juga menumbuhkan rasa percaya diri anak. Melalui penelitian semua itu akan diungkap perkembangannya melalui implementasi pembelajaran tari kreatif yang akan dikembangkan.

Penelitian ini dibuat bukan tanpa dasar. Beberapa aktivitas penelitian, kajian, maupun publikasi telah dilakukan terkait dengan pengembangan dan penguatan kompetensi penyelenggaraan pembelajaran tari, khususnya tari untuk anak usia TK. Unsur-unsur tari sebagai bagian dari seni yang dibangun melibatkan unsur sensitif manusia yaitu emosi dan kondisi psikologis secara umum. Pada penelitian ini, tari kreatif dikembangkan agar membantu anak memiliki kemampuan serta minat anak dalam pembelajaran tari khususnya untuk mengembangkan, menumbuhkan dan menciptakan suatu yang baru daya kreativitasnya melalui gerakan yang diciptakannya secara alami sehingga tercipta suatu karya seni dalam bentuk suatu tarian. Berdasarkan kajian yang telah dilakukan, tari kreatif dapat diselenggarakan dalam pembelajaran tari secara individual maupun kelompok.

\section{Metode Penelitian}

Penelitian ini dibuat dalam bentuk multi-method (Esteves \& Pastor, 2004). Morse (Tashakkori and Teddlie 2003: 189-208) mengemukakan penelitian "...multi-method is the conduct of two or more research methods, each conducted rigorously and complete in itself, in one project". Pada penelitian ini dikehendaki pelaksanaan kerja collaborativeaction-research dengan 3 siklus kegiatan tari kreatif. Anak yang menjadi subjek penelitian adalah anak kelas B TK Labschool UPI sebanyak 16 anak.

\section{Hasil dan Pembahasan \\ Bentuk pembelajaran tari kreatif un- tuk anak usia TK}

Pengembangan pembelajaran tari kreatif ini sendiri dikonstruksi merujuk pada konstruk dari Joyce dan Weil (1982), yaitu: (1) syntax, langkah-langkah operasional pembelajaran; (2) social system, adalah suasana dan norma yang berlaku dalam pembelajaran; (3) principles of reaction, menggambarkan bagaimana seharusnya guru memandang, memperlakukan, dan merespon siswa; (4) support system, segala sarana, bahan, alat, atau lingkungan belajar yang mendukung pembelajaran; dan (5) instructional dan nurturant effects-hasil belajar yang diperoleh langsung berdasarkan tujuan yang ditetapkan (instructional effects) dan hasil belajar di luar yang ditetapkan (nurturant effects). Kemudian untuk konsep kreativitas akan menggunakan konstruk yang dikembangkan oleh Jamaris (Sujiono, 2010), mencakup lima ciri perilaku kreatif tersebut yakni kelancaran (fluency), kelenturan (flexibility), keaslian (originality), elaborasi (elaboration) dan kepekaan (sensitivity). 
Selanjutnya yang terakhir tentang konsep percaya diri (self confidence) merujuk pada konsep Bush (2003) terkait tiga hal, yakni penampilan fisik, kapabilitas intelektual dan ekspresi emosi yang tepat.

Pembelajaran yang dilaksanakan di TK Lab School direncanakan cukup optimal, hal ini terlihat dari beberapa faktor diantaranya yaitu, perencanaan pembelajaran, pelaksanaan pembelajaran dan evaluasi pembelajaran. Guru membuat program semester yang dijabarkan dalam Satuan Kegiatan Mingguan kemudian dikembangkan ke dalam Satuan Kegiatan Harian (SKH). Tujuan pembelajaran mengacu pada kurikulum TK tahun 2004, namun tujuan pembelajaran di TK Lab School pun bersipat fleksibel, jika ada tujuan khusus yang ingin dicapai, maka sewaktu-waktu dapat diubah. Materi yang dikembangkan di TK Lab School disesuaikan dengan tema pembelajaran dari Departemen Pendidikan Nasional dan tema yang dibuat oleh guru TK Lab School. Materi tersebut mereka contoh dari hasil pelatihan, dari buku-buku petunjuk dan pedoman.

Metode yang digunakan di TK Lab School cukup variatif karena banyaknya ahli pendidikan anak yang terlibat. Dalam setiap kali pembelajaran metode yang sering digunakan adalah tanya jawab, bercakapcakap dan pemberian tugas. Metode yang digunakan di TK Lab School kurang memfasilitasi rasa percaya diri anak, karena metode yang digunakan hanya metode bercakap-cakap, metode tanya jawab dan metode pemberian tugas, hal ini membuat anak merasa bosan dan jenuh dalam mengikuti pembelajaran, sehingga rasa percaya diri anak tidak berkembang dengan baik, sesuai dengan yang diungkapkan Slameto (2003:65), bahwa metode pembelajaran itu mempengaruhi belajar anak.

Berdasarkan hasil penelitian, trai kreatif dapat dilaksanakan. Walaupun pada siklus pertama guru masih terlihat belum maksimal dalam perencanakan dan mempersiapkan pembelajaran sehingga suasana kelas belum terkondisikan dengan baik. Perencanaan kegiatan untuk pembelajaran pada siklus pertama ini ditentukan dari peneliti karena guru masih bingung dalam menentukan langkah-langkah pembelajaran tari kreatif.

Ketika kegiatan berlangsung, kegiatan pembelajaran tari yang dilakukan anak sudah mampu mengundang perhatian, pada saat guru menyampaikan materi pada siklus satu masih terlihat kaku dalam menjelaskan kegiatan tari yang akan dilaksanakan oleh anak karena kegiatan tari yang dilaksanakan oleh anak masing-masing kelompok berbedabeda. Dalam pembelajaran tari kreatif anak pada siklus kesatu pembelajaran masih berpusat pada guru, hal ini terjadi karena guru masih kaku dalam melaksanakan penerapan tari kreatif. Kegiatan tari kreatif dilatihkan terlebih dahulu oleh peneliti kepada guru dan guru mencontohkan pada anak untuk melakukan kegiatan tari kreatif dengan menggunakan tema binatang, tetapi karena tari kreatif binatang yang kurang dipahami oleh guru, maka dalam pelaksanaannya tidak berjalan dengan tertib dan anak-anak belum terkondisikan dengan baik.

Ketika guru mengadakan kegiatan demonstrasi tari pada kegiatan pra pengembangan anak-anak dalam mengikuti gerakan masih terlihat malu-malu dan gerakan anak masih kaku. Setelah pelaksanaan siklus satu, ternyata masih terdapat beberapa kelemahan. Guru kurang memahami langkah-langkah tari kreatif, anak-anak masih terlihat kurang percaya diri dan masih kaku dalam memberikan gerakan. Namun demikian anak-anak terlihat gembira melakukan gerakan gerakan tari kreatif.

Kelemahan di atas terjadi karena di TK Lab School masih jarang dalam menerapkan tari kreatif sehingga pembelajaran belum berjalan dengan maksimal. Selain ditemukan kelemahan dalam pelaksanaan siklus ini, ditemukan pula kelebihannya. Anak-anak yang tadinya pendiam menjadi aktif dalam menjawab pertanyaan guru karena guru banyak memberikan pertanyaan, sehingga anak-anak menjadi terstimulasi dengan adanya pertanyaan-pertanyaan tersebut.

Dari hasil siklus pertama ini, peningkatan rasa percaya diri anak dengan tari kreatif belum optimal karena terlihat dari sikap anak yang masih malu-malu dalam menunjukkan gerakangerakannya, dan hanya beberapa anak yang sudah muncul percaya dirinya, sehingga perlu direncanakan dengan maksimal dari sebelumnya, yaitu guru harus lebih hafal gerakan-gerakan tari kreatif dan menyiapkan media/alat-alat yang menarik untuk anak agar anak dapat mengkreasikan tari kreatif sesuai tema binatang.

Pada siklus dua penerapan tari kreatif sudah berjalan dengan baik, karena setelah refleksi siklus pertama dilaksanakan, peneliti dan guru merencanakan kembali mengadakan diskusi untuk merencanakan siklus kedua dengan lebih matang. Dalam hal perencanaan, 
guru sudah ikut serta dalam penelitian. Dalam pelaksanaan pembelajaran guru juga sudah terlihat lebih siap dan lebih matang dalam mempersiapkan gerakan-gerakan yang harus dicontohkan pada anak. Dalam siklus dua ini guru lebih menawarkan anak untuk berada pada kelompok tari kreatif binatang yang anak sukai dan guru memberikan properti tari.

Hal ini terlihat perkembangannya dalam pembelajaran yaitu saat guru menjelaskan tentang kegiatan yang akan dilaksanakan oleh anak sudah dapat dimengerti oleh anak. Guru juga sudah melakukan langkah-langkah pembelajaran tari kreatif dengan baik dan terlihat lebih santai dalam mengkondisikan anak pada masing-masing kelompok.

Ketika guru memberikan contoh gerakan, masih ada anak yang malu-malu mengikuti gerakan guru, namun akhirnya setelah banyak distimulasi oleh guru, anak-anak pun lebih percaya diri dan responsif terhadap gerakangerakan guru dan pada siklus dua ini anak-anak lebih banyak bertanya dan berani dalam mengungkapkan ide dan gagasannya serta dapat mengkreasikannya dalam kegiatan tari kreatif. Sebagaimana pendapat Hartono 2008) bahwa pembelajaran tari kreatif pada dasarnya berusaha untuk memperkuat dan memperlancar stimulus dan respons anak didik dalam pembelajaran, sehingga proses pembelajaran menjadi hal yang menyenangkan, tidak menjadi hal yang membosankan bagi mereka. Efek menyenangkan yang ditimbulkan stimulus akan mampu memberi kesan yang mendalam pada diri anak didik, sehingga mereka cenderung akan mengulang aktivitas tersebut.

Kelemahan yang ditemukan ketika proses pembelajaran berlangsung antara lain, anak-anak masih harus distimulasi oleh guru dalam mengikuti gerakan tari kreatif. Anakanak perempuan masih ada yang malu-malu dalam menanri, hal ini dapat disebabkan salah satunya oleh perbedaan perlakuan terhadap anak laki -laki dan perempuan. Anak laki-laki lebih diberi kesempatan untuk mandiri, didesak oleh teman sebayanya untuk lebih mengambil resiko, dan didorong oleh para orang tua dan guru untuk lebih menunjukan inisiatif dan orisinalitas. Sedangkan anak perempuan cenderung dimanja, sejalan yang diungkapkan oleh Torrance (Hurlock, 1978:8), bahwa tidak perlu diragukan bahwa sikap dan perlakuan masyarakat terhadap anak perempuan mempengaruhi perkembangan rasa percaya diri anak dan perilaku mereka.
Selain kelemahan, terdapat juga beberapa kelebihan yang terjadi ketika proses pembelajaran berlangsung. Dengan diterapkannya tari kreatif, anak-anak lebih terlihat menikmati pembelajaran dan rasa percaya diri anak terlihat. Ternyata tari kreatif ini cukup efektif untuk meningkatkan rasa percaya diri anak. Melalui stimulan pembelajaran tari kreatif anak dapat mempelajari banyak hal, tanpa ia sadari dan tanpa merasa terbebani (Rahmawati dan Kurniati, 2005:46). Anak dapat mengungkapkan ide-ide kreatif dan anak tidak kehilangan masa bermainnya.

Pada siklus ini, sudah terlihat peningkatan yang berarti dalam rasa percaya diri anak, guru sudah melaksanakan langkahlangkah kegiatan pembelajaran tari kreatif sesuai dengan langkah-langkah yang ada dalam perencanaan pembelajaran, anak sudah dapat mengungkapkan pertanyaan tanpa ragu-ragu dan tidak takut lagi dalam menunjukkan gerakan tari. Namun hasil yang dicapai belum optimal, karena hanya sebagian anak saja yang mengalami peningkatan, maka masih dirancang tindakan selanjutnya yaitu siklus tiga.

Siklus tiga ini merupakan siklus terakhir dalam peningkatan rasa percaya diri anak melalui penerapan tari kreatif. Pada siklus ini penerapan tari kreatif semakin menunjukkan perbaikan. Perencanaan yang disusun mengacu pada hasil refleksi siklus dua telah membawa perubahan pada anak menjadi lebih baik. Perencanaan yang dilakukan sudah betul-betul matang, itu terlihat dari persiapan guru dalam memahami langkah-langkah pembelajaran dalam tari kreatif. Persiapan media yang sangat menarik yang dilakukan jauh-jauh hari sebelum pelaksanaan tindakan menjadikan guru merasa sangat siap untuk melaksanakan penerapan tari kreatif.

Hasil penelitian pada pelaksanaan siklus tiga membuktikan bahwa penerapan tari kreatif dapat meningkatkan rasa percaya diri, karena dalam pembelajaran pada siklus tiga ini guru hanya berperan sebagai fasilitator, sehingga anak dapat mengembangkan potensi kreatifnya dengan leluasa tanpa dibatasi oleh guru.

Ketika pembelajaran berlangsung anakanak perempuan yang tadinya masih malumalu dalam menunjukkan gerakan tari pada siklus tiga ini sudah berani dan percaya diri karena anak-anak sudah terbiasa untuk menari di depan guru dan teman-temannya. Hal ini terjadi karena guru selalu 
memberikan kesempatan dan membiasakan kepada anak-anak untuk menari tari kreatif. Selama kegiatan pembelajaran berlangsung pada siklus tiga ini anak -anak lebih aktif dalam merespon gerakan guru dan musik yang diberikan, dan lebih percaya diri. Kelemahan dalam siklus ini adalah guru dalam mengkondisikan anak karena kegiatan anak dalam setiap kelompok berbeda-beda. Namun hal tersebut masih bisa diatasi oleh guru dengan baik, sehingga pembelajaran dapat berlangsung dengan optimal.

S e d a n g k a n k e le bi ha n s e t e I a h diterapkannya tari kreatif antara lain adalah anak-anak jadi berani tampil di depan kelas untuk menunjukkan kemampuan menari. Pada siklus tiga ini, anak-anak sudah dapat menari dengan tidak malu-malu. Anakanak juga sudah dapat tampil di depan kelas untuk menari dengan kelompoknya dengan lancar dan tanpa rasa takut lagi dan mengikuti irama musik. Hasil observasi pada siklus tiga ini dirasa sudah cukup optimal, sehingga peneliti dan guru sepakat untuk menghentikan tindakan perbaikan pembelajaran.

\section{Pembahasan}

Tujuan yang paling mendasar dari pendidikan seni tari adalah membantu anak melalui tari, untuk menemukan hubungan antara tubuhnya dengan seluruh eksistensinya sebagai manusia. Melalui penekanan kreativitas, anak diberi kesempatan yang seluas-luasnya dalma proses pengungkapan gerak tarinya, sehingga hasil akhir bukanlah merupakan tujuan utama, tapi bagaimana anak mampu untuk bergerak sesuai dengan kreativitasnya masing-masing.

Menurut Abdurachman dan Rusliana (1979), pendidian seni tari berfungsi untuk memperhalus budi pekerti manusia, sehingga sebagai warga masyarakat kelak, disamping kecerdasannya mereka juga mempunyai kepribadian dan sikap menghargai nilai-nilai keindahan dari selutuh kehidupannya. Tujuan pendidikan seni tari di PAUD adalah agar anak-anak memiliki pengetahuan, nilai, dan sikap serta keterampilan yang memadai sesuai dengan tingkat perkembangannya. Melalui pendidikan seni tari anak-anak diharapkan mampu mengungkapkan ide-ide, imajinasi, dan fantasinya secara kreatif.

Mengungkapkan perasaan, pikiran, dan gagasan anak pada sebuah gerak memang tidaklah mudah. Dalam mengembangkan imajinasi anak akan gerak, maka diperlukan suatu komunikasi yang intens, yang dapat memberikan kesempatan bagi anak-anak mengungkapkan ekspresi-ekspresi gerak secara wajar. Pengalaman bereksplorasi tersebut, memungkinkan anak-anak untuk emnemukan sesuatu yang menarik sehingga ia dapat mengetahui bagaimana bergerak, mempergunakan gerak, serta mengembangkan kemampuannya melalui simbol-simbol ekspresi yang mereka lihat, dengar, dan rasakan (Alexy \& Hafianti, 2001).

Para guru sebaiknya tidak memaksakan anak untuk mengikuti gerakan-gerakan yang sudah ada atau ditentukan. Akan tetapi, mulailah dengan mengikuti gerak alami anakanak, kemudian amati dan pikirkan tentang bagaimana anak itu bergerak.

Dalam melakukan gerakan, antara anak satu dengan yang lainnya pasti berbeda. Sebagai misal, guru meminta anak untuk berfikir tentang kelinci dan emlakukan gerakan kelinci. Maka anak akan melakukan gerak kelinci menurut imajinasi mereka masing-masing yang tentunya berbeda antar anak satu dengan yang lainnya.

Setelah anak membuat gerakan sendiri dengan imajinasinya. kemudian perkenalkan musik tahap demi tahap, yang dimulai dengan menggunakan gagasan anak-anak itu sendiri dan membiarkan mereka membuat langkah sendiri. Sebelum mengenalkan musik sebaiknya anak diperkenalkan dulu dengan bunyi. Dalam teknisnya, guru bisa memperkenalkan kepada anak- anak bunyi sebuah instrumen seperti drum, garpu tala, dan sebagainya.

Gerakan yang berasal dari anak-anak, guru dapat melihat dan mengarahkan serta memilih secara selektif gerak tersebut yang kemudian akan dijadikan bahan materi dalam penyusunan sebuah tari. Jadi sumber kreativitas (gerak) tari adalah dari, oleh, dan untuk anak. Materi dalam penyusunan tari bersuber dari anak secara individu, karena setipa anak mempunyai tingkat kreativitas yang berbeda.

\section{Kesimpulan}

Rasa percaya diri anak meningkat sejalan dengan perlakuan pembelajaran tari kreatif.

Penggunaan binatang sebagai objek pengembangan cukup mempengaruhi ide dan gerakan kreatif yang ditunjukkan dengan penuh percaya diri. 
Dibutuhkan keahlian dan kesabaran dari para guru untuk menstimulasi dan mendampingi anak-anak mengemukakan, mengembangkan, melatih dan menampilkan gerakan tari kreatif.

\section{Daftar Pustaka}

Cash, F. Thomas. (1999). Body image, development, deviance, and change. New York: The Guilford Press.

Coopersmith, S. (1967). The Antecedent Of Self Esteem. San Fransisco: W. H. Freeman \& Company.

Dinas Kebudayaan, (1988), Pedoman Pendidikan Kesenian, Jakarta.

Endang Caturwati, et. al. (2008). Tari Anak-Anak dan Permasalahannya. Bandung : Sunan Ambu STSI Press.

Kusuma, Doni.A. (2007). Pendidikan Karakter Strategi Mendidik Anak di Zaman Colonial. Jakarta: Grasindo.

Kusumastuti, Eny. (2004). Pendidikan Seni Tari Pada Anak Usia Dini Di Taman KanakKanan Tadika Puri Cabang Erlangga Semarang Sebagai Proses Alih Budaya, http://journal.unnes.ac.id/nju/index.php/ harmonia/article. diunduh pada tanggal 4 Maret 2016.

La Mery. (1965). Dance Composition: The Bacis Ellement. Lee Massachutuseets: Jakob's Pillow Dance Festival.

Morisson, George S. (2012). Dasar-Dasar Pendidikan Anak Usia Dini, Edisi Kelima. Jakarta Barat: PT Indeks.

Munandar, Utami. (2012). Pengembangan Kreativitas Anak Berbakat. Jakarta: Rineka Cipta.
Musbikin, Imam. 2006. Mendidik Anak Kreatif Ala Einstein. Yogyakarta: Mitra Pustaka.

Newman \& Newman. (2006). Development Through Life, A Psychosocial Approach (9th edition). USA: Thomson Wadsworth.

Papalia, E. Diane., Olds, W.S. Feldman D.R. (2001). Human Development (8th edition). New York: Mc Graw Hill, Inc.

Petro Alexy dan Dewi Hafianti. (2001). Ayo Menari. Jakarta: Gramedia Widiasarana Indonesia.

Powers, P.D., \& Erickson, M.T. (1989). The Body and the self. London: The MIT Press.

Rachmawati, Yeni dan Euis Kurniati. 2010. Strategi Pengembangan Kreativitas pada Anak Usia Dini Taman KanakKanak Edisi Pertama. Jakarta: Kencana.

Smith. M. Jacqueline. (1994). The Art of Dance In Education. London: A\&C Black.

Soedarsono, (2002). Seni Pertunjukan Indonesia Di Era Globalisasi. Yogyakarta: Gadjah Mada University Press.

Sri Hermawati Dwi Arini, dkk. Seni Budaya Jilid 1. Jakarta : Departemen Pendidikan Nasional.

Tashakkori, A., Teddlie, C. (2003) "Handbook of Mixed Methods in social \& behavioral research", SAGE publications.

Tri Broto Wibisono, (2001). Pendidikan Seni Tari. Surabaya : Insan Cendekia.

Widia Pekerti, dkk. (2005). Metode Pengembangan Seni TK. Jakarta : Universitas Terbuka.

Yulianti Parani, dkk. (1990). Tari Pendidikan. Jakarta: Departemen Tari, Lembaga Pendidikan Kesenian Jakarta. 